\title{
MAKNA KATA “CINTA” DALAM NOVEL DAN KARYA MUSIK KAJIAN SEMANTIK
}

\author{
Runi Fazalani \\ Pendidikan Bahasa dan Sastra Indonesia, Fakultas Keguruan dan Ilmu Pendidikan, \\ Universitas Qamarul Huda Badaruddin, \\ Alamat pos-el : runifazalani3@gmail.com
}

ABSTRAK

ABSTRACT

PENDAHULUAN
Penelitian ini bertujuan untuk mengetahui makna Cinta dari jenis dan bentuknya. Makna Cinta yang diteliti disini bersumber dari novel dan karya musik. Adapun jenis Cinta dan ciri-ciri Cinta dilihat dari sudut pandang karya sesorang yaitu. (1) cinta terhadap Allah, (2) cinta kepada diri sendiri, (3) cinta kepada orang tua, (4) cinta yang erotis, (5) cinta yang tumbuh dari rasa persaudaraan, dan (6) cinta karena nafsu. Pendekatan yang digunakan adalah pendekatan semantik leksikal. Semantik leksikal adalah suatu kajian yang lebih mengutamakan pada pembahasan sistem makna yang terdapat dalam kata. Penelitian ini menggunakan pendekatan deskriptif kualitatif. Metode deskriptif kualitatif merupakan metode yang dilakukan sematamata berdasarkan fakta kebahasaan yang ada, atau sebuah fenomena yang secara empiris hidup pada penuturnya. Penelitian ini dilakukan dengan menganalisis data yang sudah ada tanpa menambah dan mengurangi sesuai dengan sifat data yang alamiah. Sumber data penelitian ini adalah novel dan karya musik.

Kata Kunci: Makna cinta; Semantik>

This study aims to determine the meaning of love both from its type and form. The meaning of love that is researched here comes from novels and musical works. The types of Love and the characteristics of Love are seen from the point of view of someone's work, namely. (1) love for Allah, (2) love for oneself, (3) love for parents, (4) erotic love, (5) love that grows out of a sense of brotherhood, and (6) love because of lust. The approach used is the lexical semantic approach. Lexical semantics is a study that prioritizes the discussion of meaning systems contained in words. This research use desciptive qualitative approach. Qualitative descriptive method is a method that is carried out solely on the basis of existing linguistic facts, or a phenomenon that empirically lives in the speakers. This research was conducted by analyzing existing data without adding and subtracting according to the nature of the data. The data sources of this research are novels and musical works.

Keywords: The meaning of love; semantics

Makna kata suatu unsur yang dibicarakan dalam bahasa. Makna sebuah kata pada dasarnya diperoleh karena persetujuan informasi antara sekelompok orang untuk menyatakan hal atau barang tertentu 
melalui rangkaian kata atau bunyi tertentu Keraf (2002, hlm 88).

Setiap orang berhak atas kebebasan dalam mengunakan katakata saat berkomunikasi dengan orang lain. Kebebasan dalam memilih kata tiap individu dipengaruhi oleh keadaan emosi, intuisi dan intelek dari individu yang bersan-gkutan sehingga tercipta komposisi bahasa yang hanya mementingkan unsur-unsur tertentu yang diperlukan. Misalnya memilih kata-kata saat bertanya, marah ataupun menjawab diperlukan pilihan kata yang memudah lawan bicara memahaminya dan mempunyai makna yang jelas.

Berdasarkan sifatnya makna ini dibedakan atas makna yang bersifat verbal dan makna yang bersifat non-verbal. Makna verbal adalah tanda yang dihasilkan manusia melalui alat-alat bicara, dalam hal ini adalah bahasa yang berupa kata atau kalimat dan mempunyai arti. Makna non-verbal yaitu makna seperti tanda yang dihasilkan oleh anggota badan. Misalnya acungan jempol bermakna hebat dan bagus Djajasudarma (1999, hlm 5).

Cinta dari zaman dahulu sampai sekarang adalah masalah yang menarik dalam kehidupan manusia. Manusia tidak dapat terlepas dari cinta. Rasa cinta pada diri individu atau rasa cinta kepada sesama dapat diartikan seperti rasa cinta kepada orang tua, kepada anak, kepada sahabat dan kepada lawan jenis, rasa cinta itu normal dimiliki oleh semua orang.

Kata dan makna cinta banyak diucapkan oleh orang. Akan tetapi tidak semua orang dapat mengetahui makna cinta dan pembentukan kata cinta. Kata cinta apabila di analisi melalui fonem terbentuk dari lima fonem yaitu /c /i /n /t /a dengan tiga fonem konsonan dan dua fonem vocal. Makna cinta tidak ada orang yang tau karena dalam makna cinta sangat mendalam.

Homby (dalam Patede, 1989, hlm 45) mengungkapkan bahwa makna adalah apa yang di artikan oleh manusia atau apa yang di maksud. Poerwadaminta (dalam Patede, 1989, hlm 45) mengungkapkan makna adalah arti dan maksud. Kamus Besar Bahasa Indonesia (dalam Patade, 2001, hlm 82) kata makna diartikan: (i) arti : memperhatikan makna setiap kata yang terdapat dalam sebuah tulisan kuno itu, (ii) maksud pembicara dan penulis, (iii) pengertian yang diberikan kepada suatu bentuk kebahasaan. Makna adalah sebuah hubungan antara bahasa dengan dunia luar yang telah disepakati bersama oleh para pemakai bahasa sehingga terjadi sebauh kepahaman antara yang satu dengan yang lain.

Semantik merupakan bagian dari sebuah bahasa yang memiliki hubungan dengan makna ungkapan dan dengan struktur makna suatu wicara sedangkan makna merupakan tujuan pembicaraan, merupakan suatu pengaruh dalam sebuah pemahaman persepsi seseorang, serta prilaku manusia atau suatu kelompok Kridalaksana (2001, hlm 1993).

Menurut Tarigan (1985, hlm 7) semantik menelaah tanda-tanda atau lambing-lambang yang menyatakan makna yang satu dengan makna yang lain, dan memiliki pengaruh pada manusia dan masyarakat, oleh sebab itu semantik senantiasa berhu-bungan dengan suatu makna yang selalu digunakan oleh manusia atau masyarakat.

Menurut Gunarso (2002, hlm 106) cinta yang dimiliki orang adalah rasa suka terhadap seseorang sehingga ingin meng-orbankan sesuatu untuk kebahagiaan orang yang disukai, ada perasaan bahagia 
apabila dekat dengan orang yang disukai atau dicintai. Akan tetapi, apabila seseorang mencintai orang lain ingin berbuat apa saja, terlebih yang bersifat negatif ataupun positif tanpa memikirkan akibatnya kepada dirinya sendiri, cinta yang demikian ini disebut cinta buta.

Kata cinta banyak digu-nakan pada karangan wacana tulis berupa cerpen novel, puisi dan artikel di media cetak. Kata cinta apabila dilihat dari segi morfologi kata cinta tidak hanya menggunakan bentuk dasar, akan tetapi dapat berbentuk kata berimbuhan atau affix, ada imbuhan awalan (prefiks) dan akhiran (sufiks). Kata cinta dalam suatu wacana karangan terdiri atas kata asal dan kata jadian, misalnya mencintai dan dicintai. Kata mencintai dan dicintai mempunyai makna yang berbeda dan maknanya akan berbeda dengan kata dasarnya.

Cinta adalah salah satu kebutuhan pribadi manusia. Kata dan makna cinta selalu membuat semua orang menggunakannya dalam komunikasi dan berintraksi walaupun mereka tidak paham dengan makna cinta.

Kata cinta banyak digunakan pada karya sastra wacana tulis berupa cerpen, novel, puisi, dan artikel di media cetak. Kata cinta tidak hanya digunakan bentuk dasar, akan tetapi cinta terbentuk kata imbuhan awalan prefiks dan akhiran sufiks. Kata cinta dalam suatu wacana karangan terdiri atas kata dasar dan kata jadian, misalnya mencintai dan dicintai. Kata mencintai dan dicintai mempunyai makna yang berbeda.

Cinta adalah kebutuhan pribadi semua manusia. Kata cinta digunakan dalam komunikasi. Berdasarkan pemikiran tersebut permasalahan yang terjadi dalam fokus permasalahan yang menjadi rumusan masalahnya adalah bagaimanakah perbedaan makna cinta dalam karya novel, dan musik ?. Tujuan penelitian ini adalah untuk memaparkan perbedaan bentuk dan makna cinta dalam kalimat pada karya novel dan musik.

Pendekatan yang digunakan adalah pendekatan semantik leksikal. Semantik leksikal adalah suatu kajian yang lebih mengutamakan pada pemba-hasan sistem makna yang terdapat dalam kata. Semantik leksikal ini memperhatikan atau mempokuskan makna yang terdapat dalam kata sebagai satuan mandiri. Penelitian ini menggunakan pendekatan deskriptif kualitatif. Metode deskriptif kualitatif merupakan metode yang dilakukan semata-mata berdasarkan fakta kebahasaan yang ada, atau sebuah fenomena yang secara empiris hidup pada penuturnya. Penelitian ini dilakukan dengan menganalisis data yang sudah ada tanpa menambah dan mengurangi sesuai dengan sifat data yang alamiah. Sumber data penelitian ini adalah novel dan karya musik. Adapun jenis cinta dan ciri-ciri cinta dilihat dari sudut pandang karya sesorang yaitu. (1) cinta terhadap Allah, (2) cinta kepada diri sendiri, (3) cinta kepada orang tua, (4) cinta yang erotis, (5) cinta yang tumbuh dari rasa persaudaraan, dan (6) cinta karena nafsu. Teknik pengumpulan data yang dilakukan adalah teknik catat dengan langkahlangkah sebagai berikut: (1) mencatat, (2) memilih dan memilah data, dan (3) mengidentifikasi. 


\section{PEMBAHASAN Makna Cinta pada Novel dari Lembah Ke Coolibah Karya Titis Basino}

Cinta bukan hanya suatu hubungan dengan seseorang tertentu. Cinta adalah sikap seseorang yang tumbuh dalam hati tanpa tau kepada siapa, suatu orientasi watak yang menentukan hubungan pribadi dengan dunia keseluruhan, tidak hanya tertuju pada satu "objek" yaitu cinta. Cinta dapat dibedakan menurut jenisjenisnya sebagai berikut.

Cinta rasa persaudaraan. Cinta yang paling fundamental dan cinta yang sejati yang mendasari segala tipe cinta di dunia ini ialah cinta persaudaraan. Jenis cinta ini memiliki rasa tanggung jawab yang tulus lahir dalam hati tanpa mengharapkan balasan apapun, rasa perhatian, rasa respek kepada sesama, yang timbul dari suatu pengenalan sifat masing-masing dengan setiap makhluk manusia lainnya, sebagaimana yang telah dijelaskan dalam AlQur'an. Cintailah sesamamu sebagaimana engkau mencintai dirimu sendiri. Cinta kepada sesama saudara adalah rasa yang tumbuh dalam hati kepada sesama makhluk hidup. Cinta persaudaraan adalah wujud pengalaman hidup kesatuan dengan segala manusia, pengalaman solidaritas manusaiwi dan pengalaman solidaritas kemanusiaan. Cinta persaudaraan berdasar pengalaman bahwa kita semua adalah satu.

Cinta keibuan yang ada dalam novel ini adalah penguatan tanpa syarat terhadap hidup dan kebutuhan-kebutuhan anak. Penguatan (affirmasi) hidup anak mempunyai dua segi, pertama. Perhatian dan tanggung jawab dan yang, kedua adalah sikap yang menanamkan ke dalam si anak cinta akan kehidupan yang memberinya perasaan tentang hidup, tentang adanya jenis kelamin, tentang adanya dunia. Hubungan ibu dan anak pada hakikatnya adalah cinta di antara orang yang berbeda , cinta yang lahir dari kasih sayang seorang ibu kepada anaknya yang mengalir secara alamiah, dimana yang satu memerlukan segala bantuan dan yang lain memberikannya. Justru karena ciri altruistis dan tidak mementingkan diri inilah rasa cinta keibuan telah di pandang sebagai jenis cinta yang peling tinggi di antara segala cinta didunia ini dan yang paling suci dari segala ikatan emosional. Hakikat cinta keibuan ialah memelihara pertumbuhan anak, dan itu berarti tidak ada pemisah di anatara keduanya. Cinta ibu kepada anaktidak akan pernah mati sampai akhir hayat.

Cinta Diri Sendiri. Pada prinsipnya cinta itu tidak terbagi sejauh hubungan antara objek dan diri seseorang dilibatkan. Cinta yang ikhlas dan tulus adalah suatu ungkapan sifat seseorang produktif dan menunjukkan rasa perhatian, hormat, tanggung jawab kepada diri sendiri dan pengetahuan. Pengokohan hidup seseorang ada pada, kebahagiannya, pertu-mbuhannya, dan kebebasannya tumbuh dalam kemampuannya untuk mencintai dirinya sendiri yaitu dalam perhatian, hormat, tanggung jawab dan pengetahuan. Jika seorang individu mampu mencintai diri sendiri secara produktif, maka ia mencintai dirinya, jika ia hanya dapat mencintai orang lain, itu artinya ia tidak dapat mencintai sama sekali dan tidak faham akan makna cinta.

Cinta terhadap Allah. Cinta terhadap Allah merupakan salah satu cinta yang paling agung di dunia ini. Cinta yang tidak pernah dapat tergantikan oleh semua rasa cinta kepada sesama. Cinta kepada Allah tidak sama dengan cinta kepada sesama manusia dan juga cinta kepada Allah tidak sama dengan rasa cinta kepada kedua orang tua baik kepada ibu, ayah dan saudara. Allah menjadi simbol yang patut diperjuangkan untuk mendapatkan keridoa'annya. Allah adalah pencipta 
rasa cinta, kebenaran, dan keadilan di muka bumi ini untuk semua umat manusia dan kepada Allah lah manusi mengabdikan rasa cinta yang terakhimya.

Terakhir cinta erotis. Cinta yang tumbuh untuk seseorang yang lebih pribadi. Dari hakikatnya cinta ini bersifat eksklusif dan tidak universal. Keinginan seksual menuju peleburan dua hati yang berbeda jenis. Keinginan seksual juga didorong oleh rasa cemas, karena dipengaruhi oleh rasa kesombongan, rasa benci, dan rasa ingin menyakiti kepada sesama. Cinta erotis bersifat eksklusif hanya arti untuk melebur diri sepenuhnya. Mencintai pada hakikatnya memiliki keperibadian yang ada dalam hakikat keberadaannya.

Makna cinta adalah hubungan cinta yang unik rasa cinta terhadap sesama jenis. Cinta seorang nenek dengan seorang pria muda ganteng, sesuai dengan umur anaknya merupakan tema yang unik. Lumayan mengherankan dengan keadaan jiwa. Seorang nenek yang ditinggal oleh suaminya meninggal, melakukan percintaan yang tak wajar, yang membuat semua orang terheran karena mengalami cinta yang tidak biasa. Dia saling jatuh cinta pada saat dia di mekkah, dan pria muda itu adalah pembimbing calon haji dan mempunyai istri dan mempunyai anak, pria muda itu tidak merasa berdosa telah bergaul erat dengan wanita lain.

Cinta juga berada pada ranah emosional dan rasional. Cinta yang emosional ini datang dan pergi tanpa diprediksi, misalnya aku pencintaimu pada pandangan pertama dan meski aku tak bahagia bersamanya aku tetap mencintainya. Ciri-ciri cinta emosional seperti:

Pertama. Adanya perasaan yang sangat kuat, normalnya diarahkan pada lawan jenis, dimana yang ada pada pikiran serta hati adalah bayangan kekasihnya. Kedua. Adanya egoism, biasanya ada harapan-harapan bahwa kekasihnya adalah ideal yang ada dipikirannya dan merasa kecewa jika kekasihnya berbeda dengan apa yang ia harapkan. Ketiga. Cinta emosional mengandung unsur erotisme, yang biasanya ingin mengngkapkan rasa cintanya dengan berpegang tangan, berpelukan, dan sebagainya. sedangkan cinta rasional tidak didominasi oleh perasaan yang kuat akan tetapi lebih pada akal pikiran.

\section{Makna Cinta pada Musik.}

Pada zaman sekarang ini industri musik Indonesia semakin berkembang. Perkem-bangannya bisa dilihat dari peningkatan kontribusinya terhadap kualitas perekonomian negara. Menteri Pariwisata dan Industri Kreatif RI, Marie Elka Pangestu, menyatakan bahwa industri musik Indonesia telah memberikan kontribusi yang signifi kan bagi pertumbuhan ekonomi nasional rata-rata sebesar $11 \%$ per tahun sejak tahun 2010 hingga tahun 2013 (Lina, 2014). Sementara itu, dalam hal kontribusi musik terhadap Produk Domestik Bruto (PDB), pendapatan dari bidang musik mengalami kenaikan dari Rp3,9 triliun menjadi Rp5,2 triliun. Data Asosiasi Industri Rekaman Indonesia menunjukkan musik Indonesia mampu menguasai 85\% pasar musik dalam negeri dengan kecenderungan meningkat setiap tahunnya. Hal ini membuktikan bahwa produk-produk yang dihasilkan oleh industri musik tentu memiliki kuantitas yang banyak dengan perkembangan yang cukup signifi kan. Misalnya lagu-lagu yang berkaitan tentang cinta.

Cinta adalah anugrah sang maha pencipta. Cinta itu lahir dalam kalbu masing-masing orang, karena setiap orang mempunyai cinta. Rasa cinta itu tidak dapat ditebak untuk siapa dan kepada siapa. Makna cinta yang sesungguhnya adalah cinta yang lahir dari hati tanpa ada imbalan balik. Cinta itu suci, murni dan cinta tidak 
pernah salah. Akan tetapi cinta itu selalu disalah gunakan oleh manusia, terkadang ada yang memaknai cinta kepada harta, cinta kepada sesama dan juga cinta kepada Allah. Seperti pepatah mengatakan, cintailah dirimu sebelum kamu mencintai orang lain. Jadi jangan pernah mencintai seseorang kalau tidak dapat mencintai diri sendiri. Terkadang cinta itu membuat orang menjadi gelap mata. Cinta pula yang membuat orang baik menjadi jahat, orang jahat menjadi baik. Cinta itu tidak dapat di tebak, terkadang cinta itu sulit dimengerti.

Makna cinta tidak hanya membuat orang menjadi bertanya-tanya apa itu cinta? Akan tetapi manusia yang menjalani ketertarikan sesama manusia ada yang bertanggung jawab dengan cinta yang didirikan terkadang orang akan mengabaikannya.

Cinta yang didorong oleh rasa seksual akan mengakibatkan orang menjadi membenci sesama, jahat sama orang dan akan mengakibatkan Allah murka kepadanya. Akan tetapi cinta yang suci terkadang dinodai oleh orang yang tidak menghargai cinta.

Cinta dilihat dari bermacam jenis, ada cinta kepada orang tua, cinta kepada kekasi, cinta kepada sang pencipta, dan cinta kepada kekasih. Cinta itu tidak memandang usia, fisik, dan umur terkadang cinta itu membuat orang bertanyatanya. Makna cinta sulit ditebak, sulit dimengerti, sulit difahami. Terkadang makna cinta itu membuat orang bahagia, sedih, sakit dan bercampur aduk.

Banyak musisi membuat lagu berkaitan dengan cinta, dan memaknai cinta itu adalah kebahagiaan, karena cinta pula sesorang mempunyai kimestri kepada lawan jenis. Setiap bait lagu cinta dalam lagu selalu menusuk dalam jantung pendengarnya, karena selalu berkaitan dengan kehidupan manusia. Terkadang semua orang mengucapkan cinta akan tetapi dia tidak paham apa itu cinta, dan apa makna cinta. Cinta itu suci akan tetapi tinta itu di salah gunakan oleh manusia yang tidak bertanggung jawa.

Sesengguhnya cinta yang sesungguhnya adalah cinta kepada Allah, hanya kepadanya lah kita curahkan semua rasa cinta, karena dia maha pemberi cinta, dan hanya kepadanya cinta yang murni dan dialah yang wajib di agungkan dan dicintai oleh ummat manusia. Sedangkan cinta kepada sesama ada yang cinta dibalas dan ada cinta yang bertepuk sebelah tangan.

Cinta itu tumbuh dengan tiba-tiba dan tidak dapat diperkirakan dimana dan kepada siapa, entah itu dengan orang yang lebih tua dari pasangannya dan lebih muda dari pasangannya. Cinta adalah pitrah setiap manusia yang ditanamkan dari lahir. Apabila cinta itu dihargai maka cinta akan menghargai kita. Makna cinta itu rumit dan sulit di rumuskan seperti matematika. Setiap nada yang keluar dari syair lagu cinta itu bagaikan kapas yang lembut, cinta itu itu tidak hanya jalinan kasih kepada lawan jenis melainkan untuk semua yang ada di muka bumi ini. Cinta pada tumbuh-tumbuhan, cinta kepada binatang dan sebagainya.

Cinta adalah sebuah perasaan yang diberikan oleh Allah pada sepasang manusia untuk saling melengkapi, saling mengisi, dan saling pengertian satu sama lain. Cinta tidak dapat dipaksakan, cinta akan berjalan apabila kedua belah pihak ikhlas menjalaninya. Cinta tidak akan berjalan apabila diantara salah satunya mempunyai ego yang kuat. Tiada yang sempurna, setiap orang mempunyai kekurangan dank arena itu kita butuh cinta untuk menggenapinya.

Ada beberapa makna cinta dalam seni musik. Makna cinta dapat berbeda-beda bagi setiap orang atau manusia. Oleh karena itu, masingmasing kita punya kebebasan untuk mengemukakan teori tentang cinta. Cinta sering menjadi tema dalam berbagai karya seni, termasuk lagu, para musisi menuangkan persepsi mereka tentang pengertian cinta, dalam memaknainya. 
Setiap lagu itu mempunyai arti dan maknanya masing-masing. Bahkan, saking dalamnya makna lagu itu, tidak sedikit lagu yang menjadi hits sepanjang masa. Akan tetapi, terkadang ada juga lagu yang sebenarnya mempunyai makna sangat dalam namun banyak orang tidak menyadarinya. Apalagi lagu pop yang memang seharusnya identik dengan musik ceria, ada beberapa lagu pop yang mempunyai makna yang sangat dalam tanpa banyak yang tahu dengan maknanya. Studi lain mengenai pesan dalam lagu dilakukan oleh Kurniasari (2011, hlm 32-39) terhadap lagu pop berjudul Surti Tejo yang dipopulerkan oleh grup musik Jamrud.

Studi ini bertujuan melihat gambaran seksisme dan seksualitas perempuan dalam lirik lagu. Isi lirik lagu tersebut secara umum bertema percintaan antara laki-laki dan perempuan. Menggunakan perspektif gender dan analisis wacana, studi ini menghasilkan temuan bahwa seksualitas perempuan telah dimanfaatkan untuk mengonstruksi gambaran yang tidak berubah tentang perempuan di Indo-nesia.

Namun demikian, walaupun secara umum kecenderungan lagulagu pop Indonesia didominasi oleh pesan-pesan cinta yang tidak sesuai dengan realitas objektif yang ideal dalam kehidupan sosial masyarakat, namun ada juga beberapa musisi yang masih memegang teguh pesan cinta dalam membangun karya-karyanya.

Kenyataan cinta yang kadang tidak sejalan dengan apa yang kita harapkan dapat menjadikan kita lemah. Akan muncul pikiran untuk menyerah dan pergi dari hubungan yang menyiksa ini. Seperti itukah "cinta" yang ada dipikiran kita ? seorang penyayi yang bernama Craig menggambarkan dirinya yang sedang dalam perjalanan panjang menemukan cinta yang sejak awal dia impikan.

Nilai cinta sebagai pesan dalam lagu Indonesia lagu sebagai media komunikasi. Massa memiliki kemampuan untuk mentransmisikan atau menyebar-kan pesan. Media massa menjadi sesuatu yang sangat penting dan dapat menim-bulkan dampak yang cukup signifikan karena luasnya cakupan penyebaran pesan yang terjadi pada proses komunikasi massa.

Tema-tema cinta menjadi pilihan para musisi dalam menciptakan lagu, baik untuk lagu berjenis pop maupun jenis lain, seperti rock, jazz, maupun dangdut. Nilai cinta menjadi suatu nilai yang sangat penting dalam kehidupan manusia karena keberadaannya mampu mewujudkan kehidupan yang harmonis, teratur, dan seimbang.

Dasar dalam interpretasi sebuah pesan bukanlah melibatkan pesan tersebut saja, melainkan juga melibatkan pengalaman pribadi seseorang. Jika dihubungkan dengan muatan nilai-nilai yang ada pada lagu seperti lagu pop Indonesia, tentu proses menginterpretasi pesan juga perlu dilakukan sebelum pesan bisa dipahami dan diturunkan sesuai dengan fungsi komunikasi massa di masyarakat.

Cinta adalah sesuatu yang sangat luar biasa, tidak berbentuk, dan tidak tampak secara nyata, namun keberadaannya menjadi sesuatu yang suci dan alami. Berkat cinta, semua hal menjadi bisa terjadi. Tidak mudah mendefi nisikan apa itu cinta, karena cinta tidak hanya sebatas hubungan romantis, tidak hanya betapa kita membutuhkan orang lain, maupun sekedar perasaaan yang terkadang kita rasakan melalui organorgan tubuh kita. Cinta adalah konsep yang abstrak, di mana kita membutuhkan sesuatu untuk mewujudkannya yaitu dengan menjalin 
hubungan dengan orang lain Schaeffer, (2001).

Menurut Lee dalam DeVito (2007) terdapat enam tipe cinta yang didasar-kan pada istilah Latin dan Yunani, yaitu 1) eros (cinta yang berorientasi pada kecantikan dan seksualitas), 2) ludus (cinta yang hanya untuk bersenang-senang saja dan menjadikan cinta sebagai bahan hiburan semata), 3) storge (cinta yang damai, tenang, tidak banyak hasrat dan tidak melibatkan hawa nafsu di dalamnya), 4) pragma (cinta yang berorientasi pada kepraktisan dan hal-hal yang berhubungan dengan tradisi), 5) mania (cinta yang sangat ekstrim, sehingga memunculkan anggapan bahwa cinta adalah segalanya), dan, 6) agape (cinta dan kepedulian pada sesama, yang didasari oleh cinta kepada Tuhan Yang Maha Esa). Tipe-tipe tersebut diakui oleh masyarakat secara umum baik masyarakat Indonesia maupun Barat.

Melihat lagu-lagu Indonesia, nampaknya tema cinta masih menjadi primadona. Namun, tidak semua lagu Indonesia menyampaikan pesan berupa nilai cinta yang sesuai dengan realitas objektif yang seharusnya menjadi pedoman dalam kehidupan sosial masyarakat. Yuliarti (2011) mengadakan penelitian terhadap lagu-lagu pop Indonesia era tahun 2000-an. Salah satu temuan dalam penelitian tersebut adalah kecenderungan lagu-lagu pop Indonesia mengandung nilai-nilai cinta yang telah mengalami pergeseran. Nilai cinta tipe ludus (cinta yang hanya untuk bersenang-senang dan sebagai hiburan) banyak muncul. Di sini tentu memunculkan kesenjangan antara realitas media dengan realitas objektif mengenai nilai cinta. Namun sayangnya, justru lagu-lagu yang memiliki nilai-nilai cinta tipe ludus tersebut adalah lagu yang popular dengan nilai penjualan yang bagus dan sering menduduki tangga lagu di radio maupun di televisi. Senada dengan penelitian Yuliarti, Setiawan (2013) dalam artikelnya yang berjudul Pesan Moral dalam Musik yang dimuat di bumiayu.net juga memaparkan hal yang sama terkait dengan nilai-nilai yang terkandung dalam lagu Indonesia, terutama mulai pada era setelah akhir tahun 1990-an.

Salah satu musisi yang memiliki karya berupa nilai-nilai cinta yang sejalan dengan realitas objektif yang ideal adalah Yovie Widianto. Musisi ini banyak menciptakan lagu pop dengan bahasa yang lugas dan mudah dipahami. Nilai cinta dalam lagu Yovie adalah tipe storge (tipe cinta yang damai, tenang, tidak banyak hasrat dan tidak melibatkan hawa nafsu di dalamnya), bukan cinta tipe ludus (cinta yang hanya bersenang-senang). Nilai-nilai cinta tipe storge bisa ditemukan dalam lagu-lagu Yovie Widianto yang berjudul Cerita Cinta (Album Cerita Cinta tahun 1994), Tak Sebebas Merpati, Andai Dia Tahu, dan Merenda Kasih(Album Cantik tahun 1996), Engga Ngerti (Album Permaisuriku, tahun 2000), Tak Mampu Mendua (Album Cinta Sudah Lewat tahun 2003). Nilai-nilai cinta storge dalam lagu Yovie Widianto tersebut bisa diketahui dengan mengamati pada teks/lirik lagu-lagu tersebut. Selain Yovie Widianto, tentunya bukan tak mungkin ada juga musisi lain yang masih memiliki idealisme untuk memasukkan nilainilai cinta yang positif ke dalam karya- karya mereka. Hal ini perlu dilakukan agar tidak terjadi kesenjangan yang cukup besar antara realitas media dengan realitas objektif mengenai nilai cinta itu sendiri.

Realitas sosial dikonstruksi melalui tiga proses, yaitu 1) Eksternalisasi atau penyesuaian diri dengan dunia sosio-kultural sebagai produk manusia. Seperti, interaksi yang terjadi antara lagu-lagu 
yang mengandung nilai-nilai cinta dengan khalayak atau pendengar lagu-lagu tersebut. 2) Objektivasi, yaitu interaksi sosial yang terjadi dalam dunia intersubjektif yang mengalami proses institusionalisasi. interaksi yang terjadi antara khalayak pendengar lagu bertema cinta dengan pencipta lagu tersebut secara individu maupun dengan individu lain yang juga merupakan khalayak dari produk media yang sama tanpa harus melakukan pertemuan tatap muka secara langsung atau face to face. Tahap ini melibatkan proses signifi kasi, yaitu pembuatan tandatanda oleh manusia sehingga dalam proses ini bisa juga memunculkan adanya opini-opini mengenai suatu produk sosial. 3) Internalisasi, yaitu proses individu mengidentifi kasikan dirinya dengan lembaga sosial tempatnya menjadi anggota. Misalnya, munculnya persepsi dalam diri individu berdasarkan lagu-lagu yang mengandung nilai-nilai cinta yang telah mereka konsumsi.

Selain musik pop Indonesia. Musik dari luar negripun sering menciptakan sebuah lagu dengan makna-makna cinta yang terkandung di dalam sebuah lagu. Salah satu media yang sering digunakan para sufi untuk mengungkapkan cinta kepadaNya adalah lewat media lagu. tetapi untuk mengerti dari maksud sang sufi itu sendiri kau juga harus mempunyai pengetahuan dan kesadaran yang mendalam. karena bagi mereka yang kurang peka, syair-syair lagu akan seperti lagu-lagu lain, yang mengungkapkan cinta pada pujan hatinya, tapi jika kau sadara maka kalian akan menangkap bahwa ada maksud lain di balik lirik dari lagu tersebut. seperti misalnya ada pada lagu dari sebuah band yang berasal dari malaysia, sebut saja kumpulan dari Iklim, salah satu lagunya yang berjudul Suci dalam Debu. dan di bawah ini kami akan sedikit mengungkapan

\section{Makna di Balik Lagu Suci Dalam Debu by Iklim.}

Cinta tidak pernah meminta, ia senantiasa memberi, cinta membawa penderitaan, tetapi tidak pernah berdendam, tak pernah membalas dendam. Di mana ada cinta di situ ada kehidupan; manakala kebencian membawa kepada kemusnahan. Tuhan memberi kita dua kaki untuk berjalan, dua tangan untuk memegang, dua telinga untuk mendengar dan dua mata untuk melihat. Tetapi mengapa Tuhan hanya menganugerahkan sekeping hati pada kita? Karena Tuhan telah memberikan sekeping lagi hati pada seseorang untuk kita mencarinya. Itulah namanya Cinta. Jadi makna cinta pada karya music sangat banyak artinya, karena cinta diartikan bermacam-macam tergan-tung musisi yang menghasilkan sebuah karya.

SIMPULAN

Adapun kesimpulan dalam penelitian ini adalah ada beberapa makna cinta yang terdapat di dalam berbagai karya seni yang disampaiakn oleh seseorang pengarang, seperti di dalam sebuah novel, musik dan lagu, makna cinta yang disampaikan terkadang memiliki kesamaan entah itu cinta kepada Tuhan SWT, kepada nabi dan rasul, orangtua, dan kepada sesama. Novel itu dapat disimpulakan cinta antara mereka termasuk cinta berahi atau cinta yang didorong seksual yang ada pamrih. Sekalipun mereka pada dasarnya merasa berdosa dengan percintaan antara mereka, namun mereka tetap menjalaninya sehingga mengalami musibah yang menyadarkan kesalahan mereka. Cinta itu adalah anugrah yang di tanamkan oleh sang maha pencipta, yang tidak dapat dihindari oleh umat manusia. Akan tetapi cinta itu sulit dipahami oleh umat manusia. Terkadang cinta akan 
membuat orang menjadi bahagia, sedih dan menangis.

Cinta yang paling tulus adalah cinta orang tua kepada anakanaknya, yang tidak membutuhkan timbal-balik. Cinta kepada sesama selain kepada Allah dan orang tua di akibatkan oleh seksual atau pun di akibatkan oleh rasa kasihan kepada sesama.

\section{DAFTAR PUSTAKA}

Slametmuljana. (1969). Kaidah Bahasa Indonesia. Ende: Nusa Indah

Saussure, Ferdinand de. (1996). Pengantar Linguistik Umum (Penerjemah: Rahayu S. Hidayat). Yogyakarta: Gadjah Mada University Press.

Purwadarminta. (1976). Kamus Umum Bahasa Indonesia. Jakarta: Balai Pustaka.

Kempson, Ruth M. (1977). Sematics Theory. London: Cambridge University Press.

Djajasudarma, T. Fatimah. (1993). Semantik 1.Pengantar ke Arah Ilmu Makna. Ba-ndung: ERESCO. (1993). Semantik 2.Pemahaman Ilmu Makna. Bandung: ERESCO

Kridalaksana, Harimukti. (2001). Kamus Linguistik. Jakarta: PT Gramedia Pustaka.

Yuliarti Sri Monika, (2011). Lagu dan Penanaman Nilai sosial. UNS

DeVito, J, A (2007). The Interpersonal Communication Book $11^{\text {th }}$ Edition. Boston: Peorson.

Kurniasari, N. D. (2011). Seksisme dan Seksualitas dalam Lagu Pop: Kajian terhadap Lirik Lagu 'Surti-Tejo' Menggunakan Analisis Tekstual Pamator, Volume 4, hlm, 32-39.

Tarigan, Henry Guntur. (1985). Pengajaran Semantik. Bandung: Angkasa.
Gunarso, S. D. dan Gunarso, Y.S.D. (2002). Psikologi untuk Muda-Mudi. Jakarta: BPK Gunung Mulia.

Patede, Mansoer. (1989). Analisis Kesalahan. Ende Plores: Nusa Indah. 